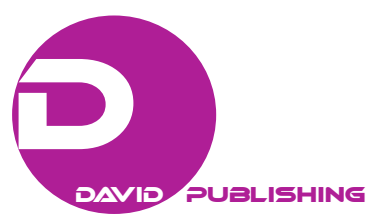

\title{
Chinese Factors in Modern Korea’s Diplomacy
}

\author{
Jin Yong \\ Communication University of China (CUC), Beijing, China
}

\begin{abstract}
In the past 65 years, China and Korea has gradually come out of the opposition misunderstanding and made essential achievements in bilateral relations since the Korean War. China has gained trust and respect from Korea through its own development and its economic interactions with Korea. As long as the Chinese economy sees no major ups and downs and there comes no major political twists and turns, China's influence in Asia and the world would be further enhanced. Korea, as part of Asia, would also be strongly influenced in the future.
\end{abstract}

Keywords: China, Korea, diplomacy

\section{Overview of Korea's 65-year Diplomacy}

The relationship between China and the Korean Peninsula is long-standing in history. In modern times, the China-Korea relations refer to the relationship between China and the Korean Peninsula. During this period, their relationship were transferring from the traditional tributary system relations to the modern treaty system relations and the latter are stressed and strengthened. This historical process spanned almost 100 years includes the second half of the 19th century and the first half of 20th century (QUAN, 2008, p. 11).

Different from the China-Korea relations in modern times, after the Second World War, the China-Korea relations especially refer to the relations between China and the Republic of Korea South of the Korea Peninsula. It has been 65 years since Korea was established on August 15, 1948. To take a basic look back to its diplomacy, we must study the main external relations of Korea. The Republic of Korea was first established as a product of the Cold War. Because of the deep differences between the north and south on the future state model, Korea was established in advance. On September 9th of the same year, the north part of the Korean Peninsula was established as The Democratic People's Republic of Korea. Starting from its foundation, the main diplomatic objects of Korea are nothing more than the United States of America, the Soviet Union (Russia), China, Japan and Southeast Asia region. After Korean War (named as "Korean War" or "6.25 War" in Korea) broke out, the diplomacy of Korea has gone through several changes:

During the Syng-man Rhee administration (Korean War), Korea pursued the policies of pro-American, anti-Japanese, and exclusion of other countries;

During the Park Chung-hee administration ("Han-jiang Miracle"), Korea continued to pursue the pro-American policy. However, because of the need for economic aid from Japan, the policy turned to be pro-Japanese, but still excluded other countries;

During the Kim Dae-jung and Roh Moo-hyun administrations (transition to democracy), Korea was still pro-American, but the concept of "treating China as friend" had been widely accepted. Korea turned tough to Japan and implement "sunshine policy" to Democratic People's Republic of Korea (DPRK). In 2000, the

Jin Yong, Associate Professor, School of International Studies, Communication University of China (CUC). 
lightening-quick success in North-South summit makes the wide nation look expectantly towards the unification. Later, Kim Dae-jung's Democrats did not succeed in congressional elections. Additionally, the North Korea did not perform this "sunshine policy" well, so many people in South Korea doubted about its real intention (Kwan, 2008, p. 121).

During the Lee Myung-bak administration (CEO President), Korea pursued pro-American policy, slightly kept distant towards China and Japan, and held a tough policy toward the DPRK.

Since Park Geun-hye came to power (as the first female head of state), Korea continued the policy of pro-American. And China follows after. Even though Park Geun-hye administration has not issued a clear policy over the issue of DPRK, its northern policy could be perceived as one between the "sunshine policy" and Lee Myung-bak's hard-line policy.

Because of the narrow land area and small population of only 50 million, Korea has always been trying hard to survive in the cracks among large countries. Therefore, its neighboring great powers have large or small, overtly or covertly influence on its diplomacy. There are many influencing factors: The first one is the evolution of the international situation; the second one is the national economic interest; the individual choice of top leaders is in the third place; and the fourth one is America. In recent years, China factor in Korea's diplomacy is gradually emerging and presenting a growing trend.

\section{How China Affects Korea's Diplomacy}

\section{Strategic Measures to Protect the Korea's Diplomatic Space}

Since 1949, because of the breakout of " 6.25 War", China and Korea had wars. After about 30 years, the bilateral relation was extremely cold. When China and Korea established diplomatic relation on August 24, 1992, the bilateral relations developed rapidly. During the past 20 years, on major strategic level, China has played a role as the cornerstone of peace and stability in East Asia and the world rules practitioner, achieving important strategic fit between China and Korea and protecting Korea's diplomatic space from suppression.

\section{Criticism from China to DPRK's Missile Tests}

On October 9, 2006, DPRK conduct nuclear tests despite of the strong opposition from the international community. Chinese Foreign Ministry immediately issued a statement on the same day. Contents include: On October 9, DPRK ignored widespread opposition from the international community, flagrantly conducted the nuclear test, the Chinese government is firmly opposed.

However, DPRK has not given up nuclear fantasy. On May 25, 2009, DPRK ignored universal opposition from the international community and conducted another nuclear test. Chinese government reiterated its firm opposition.

In the Peninsular nuclear issue, China advocates denuclearization of the peninsula, like the international community do. China strongly urges the DPRK to honor its commitment to denuclearization, stop all the actions which may result in further deterioration of the situation and return to the negotiating table. Meanwhile, according to the resolution adopted by the UN Security Council, China imposed trade sanctions on DPRK.

According to the current comparison of military powers on the Korean Peninsula, Korea is not dominant. Faced with DPRK's threats to "let Seoul burn in flames", China's fair and responsible attitude is undoubtedly valuable support to Korea.

International media generally believe that DPRK's capriciousness has demonstrated that it is not a "good 
boy" of the "global village". This phenomenon becomes more evident since Kim Jong-un came to power after the death of Kim Jong-II. If one country can still have a little restraint to Korea who acts like a rogue, then this country can only be China. Professor ZHU Feng from Peking University believes that DPRK abandoned its nuclear program is not just an obligation of Korea; and it is not just the task of United States, DPRK, Korea. All members have a responsibility to build new security construction in this area. ${ }^{1}$ China makes every effort for the nuclear talks, and is by far the most reasonable model to seek denuclearization talks. It can ensure the denuclearization of the Korean Peninsula, but also take DPRK's immediate safety in consideration.

Overall, the international community highly praised for China's firm stance on the nuclear issue. It is consistent with Korea, which has always opposed the goal of denuclearization on the Korean Peninsula. China's firm stance on the nuclear issue on the Korean Peninsula deters DPRK's militarism thought, prevents DPRK from becoming a runaway horse, and also leaves much room to maneuver for Korean diplomacy.

\section{China's Support to Ban Ki-moon as UN Secretary-General and his Re-election}

In 2007, former Korean Foreign Minister Ban Ki-moon was elected Secretary-General of the United Nations. The attitudes of five permanent members of the UN Security Council are essential. China's support to Ban Ki-moon won praises from top to bottom of Korea.

After taking office in 2007, Ban Ki-moon stressed that he was the first Secretary-General of Asian values. Since then, his "inaction" style has continually being talked about. Korean media said, in the past four and a half years were both hard and bumpy for Ban Ki-moon. Early in office, Ban Ki-moon's leadership was questioned by UN members. Attached importance to "persuasion" and "mediation", Ban Ki-moon was appraised by Western countries as a "Secretary-General lacking leadership", and was thought by developing countries to be pro-America.

In Ban Ki-moon's process of seeking re-election, China once again gave valuable support. Ban Ki-moon's successful re-election as Secretary-General of the United Nations is one of the most important embodies of Korea's international influence.

China's supports to Korea in the matter of national interest and national image undoubtedly inject new vitality to enhance Korea's diplomatic ability.

\section{Economic Interaction Tamps Korea's Confidence on Diplomacy}

China's opening-up policy in the economic field benefits Korea a lot. Taking the opportunity of the 1988 Olympics in Seoul, the communications between China-Republic of Korea (ROK) were getting increasingly active and the China-ROK relations were improved (SHEN, 2008, p. 166). As the world's most populous country and the world's second largest economy country, China has brought great business opportunities to the Korean market. Statistics show that in 2012 China-ROK trade volume was $\$ 215.1$ billion. $^{2}$ During the 20 years since China and Korea established diplomatic relations on August 24, 1992, bilateral trade increased by 31.6 (from $\$ 6.4$ billion to $\$ 215.1$ billion). The data published by China Industry Advisory Network also show that China is Korea's largest trading partner, its largest export destination and largest source of imports.

Today, Korean enterprises are almost everywhere in China: in China Export Fair held in Guangzhou, the number of Korean companies in the exhibition occupied the first place for a long time. In Xingsha District in Changsha, Hunan Province, signs and billboards have Korean labels. Korea's new president, Park Geun-hye

\footnotetext{
1 Retrieved from http://www.china.com.cn/news/txt/2007-11/11/content_9209305.htm

${ }^{2}$ Retrieved from http://kr.mofcom.gov.cn/article/ztdy/201301/20130100011238.shtml
} 
mentioned in her autobiography The Exercise from My Despair that: In November 2006, there are 2000 Korea Korean enterprises and 20,000 inhabitants settled just in Yantai, Shandong Province. China-ROK economic interaction, especially large number of Korean companies in China, makes China-ROK relations inseparable. There was a little bit of me in you and a little bit of you in me. Diplomacy towards China is an important part of Korea's diplomacy.

At the same time of Korean companies seeking chances to settle in China, Chinese enterprises begin to enter Korea. According to Korean media's report in 2011, during 10 years, Chinese enterprises in Korea increased about 2.8 times. It is the largest increase among foreign-invested enterprises. Among Chinese enterprises entering the Korean market, the most investment industry is the wholesale and retail trade, accounting for $64.9 \%$ of total number of enterprises, then follows manufacturing, services, transportation, communications, finance and insurance, catering and accommodation, and other industries.

In today's world, the concept of "economic priorities, interests first", without exception, has become country's foreign relations guideline. Thanks to highly active economic relations between Korea and China, Korea always takes friendship into account in dealing with disputes and other sensitive matters, such as Chinese fishermen stabbed Korean police because of the fishery dispute and other cases. Disputes can always eliminate in the bud and will not expand.

China, as Korea's export market, greatly promoted Korea's economic transformation, and enhanced the overall economic strength of Korea. Korea's total economic output in 2007, once approaching the world's top ten, ranked world No. 11. Yonhap reported on January 28, 2013 that in 2012 Korea's GDP was 1.10346 quadrillion Korean Won (KRW), and the per capita GDP was 2207 ten thousand KRW $(\$ 22,000)$. The World Economic Forum announced the national economic strength rankings in 2012: Korea ranked 19 among 144 countries, which increased 5 ranking places compared to $2011 .^{3}$

The leap of Korea's economic strength significantly enhanced its sense of independence in the diplomatic field. A typical example is former presidents Kim Dae-jung and Roh Moo-hyun who were politically left pressure America again and again to "recover the wartime operational control" during the administration. In 2006, the Korean Defense Ministry symbolically received 15 US military bases setting in the places near the military demarcation line on Korean peninsula, such as Munsan, Paju, Dongducheon, and Uijeongbu. It marks America's return of military bases to Korea. ${ }^{4}$ According to agreement between the US and Korea, by the end of 2011, 59 of more than 70 US military bases and facilities were returned back to Korea.

\section{Military Enhancement Protects Korea's Diplomacy Space}

From the beginning of new century, China spares no effort in building a strong national defense. Not only the birth of the first aircraft carrier "Liaoning", China's rapid progress in the field of outer space, as well as constantly updated submarine technology also shows that China's determination to guard state territory and its sovereignty over territorial waters.

It seems that China maintaining a strong military has put pressure to Korea's diplomacy. But it actually protects the security of East Asia. To Korea, it does more good than harm. This is the reason why every time when China developed new weapons or launched Shenzhou series of probes into space that the United States

\footnotetext{
${ }^{3}$ Retrieved from http://ts.hjenglish.com/subject/sc/page/419548/WEF의 2012년 국가경쟁력. In 2012, Among 144 countries, the National Competitiveness of Korea increased 5 ranking places compared to last year.

${ }^{4}$ Retrieved from http://www.huaxia.com/thjq/jsgc/jsgcwz/2010/06/1924531.html
} 
expresses concerns and Japan becomes restlessness, but Korean media have less negative judgment. Korean media have fewer reports about China threat theory because in their subconscious they are optimistic to see the enhancement of China's military power, which shows China's determination to maintain peace and stability in Northeast Asia. After all, the rise of a responsible country could provide strategic security to Korea.

Back in 2008, Korea's World News published an article saying that "China was proving to the world that it is a force to contain American unilateralism and it was necessary for Korea to develop long-term strategies to cope with it. However, Korea so far only takes China as an economic partner, with the rise of whom its national interest become increasingly difficult to implement. Korean government should get themselves more involved in the new world economic order in which the rise of China has been recognized". 5 On April 21, 2009, Korea's Joongang Daily for the first time put forward the concept of "Chin-Korea". 6 The paper suggested the Korean government that "if China's trend to become a super power was inevitable, then we should make use of it to develop ourselves rather than block China's rise". This article also conveyed the idea that only when Korea get rid of the unprovoked fear of China, could Korea develop along with China. On November 14, 2011, Korea's Joongang Daily published a signed article saying that China's rise is Korea's Gospel, which should be maintained. The article said "in the past 20 years, the presence of China is our gospel"?

Lee Sam-Seong, professor from political administration of Korea Hallym University, in his book War and Peace in East Asia, has presented a new perspective to see China, saying that the so-called "China threat theory" is lack of basis. The book said that from historical experience, When China was in prosperity and stability, there was almost no war in the Korean peninsula. When China was politically unstable, the Korean Peninsula also fell into nightmare, such as "Mongol invasion", "Rat casually", "Japanese Invasion chaos", "Korea-Japan merger", etc. ${ }^{8}$. In history, aggression on the Korean peninsula was never from the Chinese, but from China's neighboring countries such as Mongolia and Japan, which also had designs on China. ${ }^{9}$

\section{Korea's Identification with Chinese Culture Enhances its Diplomacy}

For more than 1000 years, a cultural exchange between China and Korea has been the solid foundation of the two countries' relations. For a long time, Korea had proudly claimed itself as a smaller group of Chinese. Korea's unique topography and location has determined that it would absorb and carry forward the Confucian culture, which has been perceived by the Chinese positively. In Korea, people of the upper class, such as entrepreneurs, are often proud that they have much knowledge on Chinese classics. Despite the invention of Hunmin Jeongeum by King Sejong, the pronunciation and font of Korean still have its Chinese traits, which is the essence of Korean culture and soul.

The Chinese people always adopt very welcome attitude toward the Korean culture, especially those historical costumed drama that present Confucian culture and oriental traditions. For those Chinese who have experienced China's Cultural Revolution, it's really happy to see the development and heritage of the Chinese culture. For example, former Chinese President HU Jintao likes the Korean TV drama "Dae Jang Geum" very much.

The cultural similarities have resulted in Korea's "China complex". In diplomacy, this "China complex"

\footnotetext{
5 Retrieved from http://news.sohu.com/20080722/n258290645.shtml

${ }^{6}$ Retrieved from http://international.dbw.cn/system/2009/04/22/051874289.shtml

7 Retrieved from http://china.huanqiu.com/eyes_on_china/economy/2011-11/2183451.html

8 These all refer to historical events related to the Korean peninsula.

${ }^{9}$ Retrieved from http://news.sohu.com/20100528/n272412318.shtml
} 
becomes a little similar to the Oedipus complex. Former Korean President Roh Tae-woo has paid a special visit to Linzi, Shandong province of China only because his surname originates from the Chinese surname Jiang. Besides, representatives of Ban Ki-moon have confirmed that his departure is in Xingyang, China.

China's recognition of Korea's culture, including television drama, food, clothing, cosmetic surgery and animation, promotes Korea's public diplomacy toward China. The culture of Korea is one of the major attractions for Chinese students to study in Korea. According to a survey in 2010, from 2004 to 2010, the number of Chinese students in Korea increased nearly 10-fold, reaching 53,461, accounting for 70\% of Korea's foreign students. Besides, visits between the two countries increased 35 times (from 130 thousand times to 4.54 million times).

Because of such extreme importance of China, in 2010, Korean Foreign Ministry decided to add several departments to strengthen diplomatic power toward China, and planned to set up specialized agencies to study China's "dislike-Korea sentiment". In addition, the Korean Foreign Ministry also planned to set up a "dislike-Korea sentiment Management Group", so as to carry out systematic analysis on China's history, culture and public opinion, and to strengthen the friendly relations between Korea and China. ${ }^{10}$

It is no exaggeration to say that, the influence of Korean culture on China has surpassed that on East Asia, Europe and America. In other words, China is the biggest recipient of Korean culture. Without China's widespread recognition, Korea's public diplomacy will be impaired. According to a plan of the Korean Foreign Ministry, in 2013, the Korean government arranged a 20 billion (about 1.1 billion Yuan) budget to support its public diplomacy, including building and maintaining web portals, carrying out public diplomatic activities, etc.. $^{11}$

\section{Korea "Pro-China" Diplomacy Not Formed yet}

Some might say that throughout the past 65 years, Korea's foreign policy on China has changed from hostile to friendly, from friendly to intimate. Although the two countries have established seemingly close political and economic relations, it has to be pointed out that, Korea's diplomacy toward China is just on the "Friends of China" level, not to the "pro-China" level. The reason is as following.

\section{The Interference from the United States as an Objective Matter}

Because of the military intervention of the US, Korea survived the Korean War. As a result, Korean people began to warship the US and started to claim Korea as "Little America". Under the impact of international environment, the party politics appeared to a pattern of "one-sided Conservative Party" and it continues to the present day (ZHENG, 2008, p. 208). Different from its attitude toward Japan and China, Korea has been thankful to the US for six decades. Besides, safeguarded by the large number of American troops stationed in Korea, Korea's diplomacy toward China has to be constrained by the United States.

In today's anti-China wave, Korea's dependence on the US and compliance with it has determined that many Koreans would still doubt China's peaceful development. Therefore, Korea's diplomacy toward China changes on occasions.

\section{The Cognition and Standpoint of National Leaders}

As Korea's foreign policy making power comes from the Blue House, it often depends on the national

\footnotetext{
${ }^{10}$ Retrieved from http://www.chinanews.com/gj/2010/11-16/2659109.shtml

11 Retrieved form http://www.chinadaily.com.cn/hqgj/jryw/2012-07-30/content_6580334.html
} 
leaders. Syng-man Rhee and Park Chung-hee, both of them are tough anti-communist politician. When Roh Tae-woo came to power, his northern policy had rapidly warmed China-Korea relations and Korea's relation with the former Soviet Union. The establishment of diplomatic relations between China and Korea was achieved at this period. Then, Kim Dae-jung came into power. Due to his profound knowledge on Chinese culture, he had very friendly feelings for China. During his presidency, he established deep friendship with Chinese leaders through several visits to China.

Current Korea president Park Geun-hye is very proficient in Chinese who joked that her first boyfriend was China's military hero from the Three Kingdoms period. After the assassination of her parents, Park Geun-hye read the writings of Chinese philosopher FENG Youlan carefully. It can be said that in her most lonely and helpless moments, Chinese philosophy had given her strength. After Park Geun-hye was elected, she came to China in her second visit as a president and named this visit as "the Journey of Hearth and Faith". During her visit in China, she delivered a speech at Tsinghua University in Chinese language and mentioned that Korea would return the remains of Chinese servicemen during the Korean War. Her modest and friendly manner has won praise of many Chinese. Park Geun-hye believes in and insists on principles in her political life and her political philosophy is "Walk the talk" (Chun, 2014, p. 182). It is no doubt that during the five-year presidency of Park Geun-hye, Korea would further enhance China-Korea relations.

\section{The Diplomatic Principle of " Keeping-low-profile" of China}

After the Korean War, China-Korea relations had fallen into a hostile state for a long time. However, since China's reform and opening up, China has started to adopt an independent and peaceful foreign policy, which does not form any alliance with major powers, and does not make use of its identity as a big nation. Since the great upheaval in Europe and China's political disturbances in the year 1989, China started to adopt a low profile strategy, namely unemotional and conservative. On the issue of China's neighboring countries, China adheres to the principle of non-interference in internal affairs. For example, in 1998, China's reaction to the large-scale persecution of Chinese in Indonesia was very calm. In 2010, dealing with the "Cheonan crisis" between DPRK and Korea, China's attitude was still blurred.

The key of the principle of keeping-low-profile is to enhance development while keeping low profile. Just as former Chinese President JIANG Zemin said, "to make fortune without speaking aloud". But the reality of the international environment and the harsh global competition have made it clear that blindly adhering to this policy would bring China harm. Because, as a big country with 1.3 billion people and a permanent member of the UN Security Council, China is doomed to face the international community and the anti-China forces. As Kishore Mahbubani, Singapore's famous scholar pointed out: If Chinese leaders wanted to use their own peace and quiet rise to achieve global dominance, then it may be too naive and stupid. Sooner or later the United States would wake up from the geopolitical slumber. Some signs already show that it has opened up a sleepy eye. He even described vividly that China is a large house at the center of a village, which is constantly expanding. Of the seven billion people on earth, China accounts for 1.3 billion. When this group of people becomes stronger, the rest of the world would naturally feel the pressure. Therefore, it is natural for China to have difficulties in dealing with its relations with other countries. He suggested that China's foreign policy must be more proactive. China should take the initiative to reach out to other countries and to understand the needs of other countries. ${ }^{12}$

\footnotetext{
12 Retrieved from http://news.xinhuanet.com/world/2012-12/11/c_124076169_4.htm
} 
Influenced by the diplomatic principle of keeping-low-profile, China's diplomacy is lack of confidence. In the world that Europe and America dominates public opinion, comments and criticism from the west has made China more hesitant. In the long run, such policy would breed weak mentality and inferiority complex. In a world, keeping-low-profile apparently brings more harm than good.

Luckily, after the 18th National Congress of the Communist Party of China, the Chinese foreign policy is slowly getting out of "low profile", but gradually emphasizes that China should "do something". In the report of this meeting, it has been noted that China should have confidence in its own way, its own theories and its own policies. After XI taking office, China has begun to get the initiative in dealing with affairs with neighboring countries. In the dispute with Japan over the Diaoyu Islands, the dispute with the Philippine over the South China Sea and territorial disputes with Vietnam, China's proactive and responsible attitude is refreshing for the rest of the world.

\section{Conclusions}

In the past 65 years, China and Korea has gradually come out of the opposition misunderstanding and made essential achievements in bilateral relations. China has gained trust and respect from Korea through its own development and its economic interactions with Korea.

In the coming years, as long as the Chinese economy sees no major ups and downs and there comes no major political twists and turns, China's influence in Asia and the world would be further enhanced. Korea, as part of Asia, would also be strongly influenced.

Since ancient times, the success of a country has never come from weakness and concession. This is especially true for big countries. Even some small countries have the courage to achieve success through adventure. For example, Ito Hirobumi provoked the Sino-Japan War, Heihachiro Togo attacked Russia, both to increase the power of Japan. However, China should comply with international rules, and must have a clear international perspective. This is the correct foreign policy, which suite not only China, but Korea as well.

\section{References}

Chun, Y. S. (2014). Leadership of loneliness. (Q. Ri, Trans.). Beijing: China Machine Press.

Kwan, W. Y. (2008). South Korea's diseases. (X. Y. Bin, Trans.). Beijing: Xinhua Publishing House.

QUAN, H. X. (2008). Selected documents on the Sino-Korea modern relations. Beijing: World Knowledge Publishing House SHEN, D. C. (2008). South Korea's diplomacy and the United States. Beijing: Social Sciences Academic Press.

ZHENG, J. y. (2008). South Korean political parties. Beijing: Social Sciences Academic Press. 